\title{
Ant Abundance, Identification and Relation with Cocoa Pest Attacks Under Several Shade Trees
}

\author{
Abied Khafidhan ${ }^{\left.1^{*}\right)}$ Rahayu Widyastuti ${ }^{2)}$, and Soetanto Abdoellah ${ }^{3)}$ \\ ${ }^{1)}$ Laboratory Soil Biotechnology and Environment, Graduate School, IPB University, Bogor, Indonesia \\ ${ }^{2)}$ Department of Soil Science and Land Resources, Faculty of Agriculture, IPB University, \\ Jl. Meranti Kampus IPB, Dramaga, Bogor, Indonesia \\ ${ }^{3}$ Indonesian Coffee and Cocoa Research Institute, J1. PB. Sudirman No. 90, Jember, Indonesia \\ ${ }^{*}$ Corresponding author: khafidhabied@gmail.com \\ Received: 14 July 2021 / Accepted: 1 November 2021
}

\begin{abstract}
Ant is soil macrofauna that may play essential role in preventing pods of cocoa (Theobroma cacao L.) from Helopeltis antonii and Conopomorpha cramerella attacks. However, the method of controlling those pests primarily use pesticides which leave residue than can disturb ant life. This research was conducted at Kaliwining Experimental Station of Indonesia Coffee and Cocoa Research Institute, Jember. The aims of this study were to determine the abundance and diversity of ants in cocoa plantations with different type of shades, namely leucaena, areca palm, coconut, oil palm and paranet as control and to determine the correlation between ant abundance and intensity of $H$. antonii and $C$. cramerella attacks. Ants sampling was carried out using pitfall traps and Berlese funnels based on purposive sampling method. The results showed that six subfamilies of ants were found in all observation sites. Subfamily Myrmicinae was the dominant group in all observation sites. The ant abundance has a negative correlation with intensity of both pest attacks, which was influenced by the association between ant and mealy bug (Planococcus sp.) around cocoa pod.
\end{abstract}

Keywords: ant, cocoa pod, Helopeltis antonii, Conopomorpha cramerella

\section{INTRODUCTION}

Cocoa production plays an important role in the plantation sub-sector and in the national economy of Indonesia. However, cocoa cultivation currently faces many obstacles, including the presence of plant diseases and pests that can reduce the quantity and quality of cocoa production. The main pests responsible for decreasing cocoa fruit production are the cocoa pod borer (CPB) or Conopomorpha cramerella and Helopeltis antonii.

H. antonii is a pest in cocoa plantations which responsible for damaging cocoa pods and young shoots by absorbing cell sap of the pod (Pravita et al., 2020). Cocoa pod attacked by $H$. antonii has characteristics such as black or brown spots on the skin, dried pod, inhibited pod growth, and shrinked pod. Cocoa pod borer (C. cramerella) attacks cocoa crops in almost all major cocoa-producing areas in Indonesia. This pest attacks cocoa pods in young stage until ripe. This pest attack can reduce the quality and quantity of cocoa bean by more than $80 \%$ (Sulistyowati et al., 2003). Cocoa pod borer lays eggs on the furrows of the pod husk. After the eggs hatched, the larvae bore the skin, eat the pulp and make a tunnel among beans, so that the beans clumped (Rubiyo \& Siswanto, 2012). 
Cocoa pod attacked by cocoa pod borer has characteristics, namely faded skin color, green-yellow stripes or red-orange stripes appear, the beans strongly sticked each other. C. cramerella attacked 60,000 ha cocoa plantation in Indonesia and causing a loss of USD 27 M.year-1 (Ditjenbun, 2021).

The attack of cocoa pod borer and cocoa mosquito bug (Helopeltis antonii) can decrease cocoa yield until 80\% (Armaniar \& Saleh, 2018). Insecticide application not only reduce pest attack but also the useful organisms. Moreover the residue of the pesticides usually need a long time to be degraded.

One of the useful organisms that is influenced by insecticide application is ant. Ant is the organism that play important role as pollinator, decomposer, predator, bioindicator, ecosystem engineer, and biocontroller (Rahim \& Ohkawara, 2019; Rahayu \& Wiryadiputra, 2019). Ants that can be used as biocontrol are present in Dolichoderus group. The ant genus Dolichoderus will associate with mealybugs (Planococcus sp.) that stick on the surface of the cocoa pod skin. Dolichoderus sp. will surround cocoa pod consequently $H$. antonii and C. cramerella can not hatch cocoa pods to absorb fruit juices.

In cocoa plantations, ants can be found in shade trees and cocoa trees, but ants are more interested in making nests on and below the ground surface, litter, under rocks, due to the influence of environmental temperature (Ikbal et al., 2014; Frouz \& Jilková, 2008; Rocha-Ortega \& GarciaMartinez, 2018). Air temperature can affect nest structure, shape, size, location and ant behaviour (Frouz \& Jilková, 2008; Kadochová \& Frouz, 2014). According to Kadochová \& Frouz (2014), air temperature influence the behavior of ants in determining where to find food. Ants in locations with low temperatures will look for food in places with higher temperatures like trees, and vice versa ants in locations with high tempera- tures will look for food in places with low temperatures like litter and below the rocks (Paris \& Espadaler, 2012).

Ant has an essential role to develop ecosystem, but the application of pesticide and human activity can disturb ant life. The aims of this study was to determine the abundance and diversity of ants in cocoa plantations with different type of shade (leucaena, areca palm, coconut, oil palm, and paranet as control) and to determine the correlation between ant abundance and intensity of $H$. antonii and C. cramerella attacks.

\section{MATERIALS AND METHODS}

This research was conducted at Kaliwining Experimental Station, Indonesian Coffee and Cocoa Research Institute (ICCRI), Jember, East Java, Indonesia, from August to November 2020. The observation sites were selected based on the purposive sampling method represent to each shading condition. Observation was carried out in five blocks of cocoa plantation with different shading types, namely paranet, leucaena, areca palm, coconut, and oil palm. Farming practices such as weeding, fertilizing, pestcontrolling, followed the standard cocoa contribution applied in this plantation.

Microclimate condition (air temperature and humidity) in Kaliwining Experimental Station was measured using TH108 Thermohygrometer which was hung at the middle of the cocoa plantation on each block and left for 24 hours. All parameter on microclimate condition was carried out 3 times in each observation plot.

Ant and soil sample were taken under the tree of cocoa of Sulawesi 01 clone at $50 \mathrm{~cm}$ from cocoa tree. Ant samples were taken using two methods, pitfall traps and Berlese funnels. Each cocoa shade treatment was divided into 3 observation plots size of $20 \mathrm{~m}$ 
x $20 \mathrm{~m}$ (Figure 1). Therefore, the total trap sites that used for each treatment was 30 sites (15 sites for pitfall trap and 15 sites for Berlese funnel).

Air dry soil samples were analyzed for organic $\mathrm{C}$ (Walkey and Black method), $\mathrm{pH}$ $\mathrm{H}_{2} \mathrm{O}$ (pH meter method) and total $\mathrm{N}$ (Kjeldahl method). The parameters of the physical properties analyzed were soil moisture (gravimetric method), particle density (pycnometer) and bulk density (ring method).

Extraction of ant samples from a modified Berlese funnel was carried out at the Soil Laboratory of ICCRI. The principle of the Berlese funnel uses ant's habit for which avoiding heat (thermoregulation). The sorting process, identifying, and taking sample photos were carried out at the Laboratory of Soil Biotechnology, Department of Soil and Land Resources, Bogor Agricultural University. Ant identification was conducted until subfamily level using the Australian Ants Key: Their Biology and Identification (Shattuck, 2001), and the Identification Guide to the Ant Genera of the World (Bolton, 1994).

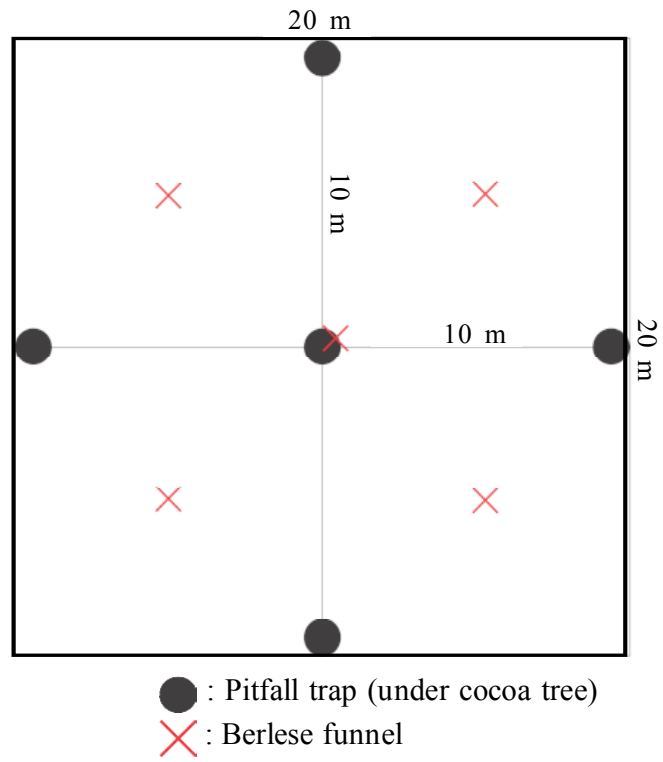

Figure 1. Schematic of sampling point in each observation plot
Samples of 60 cocoa pods were taken from each observation site. The pod surface and cocoa beans were observed. The pod that was attacked by $C$. cramerella (CPB) was observed by looking at the attached (clumped) beans and the pod that was attacked by $H$. antonii was observed by looking at the black or brown spot on the pod surface (Suherlina, 2020; Nenotek, 2018). The intensity of the pest attacks was calculated using the following formula (Suharlina, 2020; Nenotek, 2018):

$$
\mathrm{I}=\frac{\sum(\mathrm{NixSi})}{\mathrm{NxS}}
$$

$\mathrm{I}=$ pest attack intensity

$\mathrm{Ni}=$ number of pods attacked on the certain scale $(0,1,2,3,9)$

$\mathrm{Si}=$ specific attacked scale

$\mathrm{N}=$ total number of pods observed

$\mathrm{S}=$ the highest scale value

Data were analyzed with the ShannonWiener Diversity Index (H') and the Evenness Index (E). The Shannon-Wiener Diversity Index (H') was calculated by the formula (Dinesh et al., 2018):

$$
\mathrm{H}^{\prime}=-\sum_{i=1}^{S}\left(\frac{n i}{N}\right)\left(\ln \frac{n i}{N}\right)
$$

$\mathrm{H}^{\prime} \quad$ = Shannon-Wiener Index

$n i \quad=$ number of individuals of species $i$ in the sample

$N \quad=$ total number of indivuals

If,

$\mathrm{H}^{\prime}>3=$ high diversity and stable ecosystem $1<\mathrm{H}^{\prime}<3=$ moderate diversity and stable ecosystem $\mathrm{H}^{\prime}<1=$ low diversity and unstable ecosystem

Evenness Index was calculated by formula (Olawusi-Peter \& Ajibare, 2014):

$$
E=\frac{H^{\prime}}{\ln (S)}
$$

$\mathrm{E}=$ Evenness Index

$\mathrm{H}^{\prime}$ = Shannon-Wiener diversity index

$\mathrm{S}=$ Number of observed species 
The range of evenness index is $0-1$. If the evenness index is close to 0 (zero), indicating there was a dominance of the species in the area. If the evenness index was close to 1 (one), indicating that all species in the area have the same composition (no dominant species) (Haneda et al., 2013).

Shannon-Wiener index is a basic indicator of species diversity and abundance (Dinesh et al., 2018). According to Evangelista et al. (2012), in analyzing ecology, at least two calculations are required that involve community attributes (the number of species and their relative abundances). Shannon-Wiener index $\left(H^{\prime}\right)$ and Evenness index $(E)$ is an intermediate measure that balances both diversity attributes (Melo, 2008).

\section{RESULTS AND DISCUSSION}

The differences in microclimate were influenced by the different type of shades in the area. Vegetation with a larger canopy tends to keep microclimate conditions more humid (Niether et al., 2015). Under paranet site, the temperature was lower, whereas the humidity was higher than other shade (Table 1).
The diversity of ants in each shade treatment is caused by the differences in environmental conditions and vegetation types in each plantation (Zina et al., 2021). The number of ants trapped with the pitfall trap and Berlese funnel was 3979 ants and 493 ants, respectively, which were divided into six subfamilies (Table 2). The existence of the subfamily Myrmicinae, Ponerinae, Ceraphachyinae, Aenictinae, Dolichoderinae, and Formicinae were found in each shade treatment. The number of ants obtained by the pitfall trap method is more than the Berlese funnel method, because the pitfall trap method is a suitable method for taking arboreal, diurnal, and nocturnal arthropods, whereas Berlese funnel method only takes arthropods from underground (Rosa et al., 2019). Based on unpaired T-test, ants taken using pitfall trap method were significantly different from Berlese funnel (P-value $<0.05$ ).

The highest ant populations were found at the oilpalm and paranet sites, with the Myrmicinae subfamily as many as 1332 ants and 1050 ants, respectively (Table 2). The Myrmicinae subfamily dominates over the other subfamilies in paranet and oilpalm site because this subfamily is known as tramp

Table 1. Microclimate and soil properties in cocoa farms with five shade types

\begin{tabular}{|c|c|c|c|c|c|c|c|c|c|c|}
\hline \multirow{3}{*}{ Shade } & \multicolumn{2}{|c|}{ Microclimate } & \multicolumn{5}{|c|}{ Soil chemical properties } & \multicolumn{3}{|c|}{ Soil physical properties } \\
\hline & Temper & re $\left({ }^{\circ} \mathrm{C}\right)$ & \multirow{2}{*}{$\begin{array}{l}\text { RH } \\
(\%)\end{array}$} & \multirow{2}{*}{$\begin{array}{c}\text { Organic C } \\
(\%)\end{array}$} & \multirow{2}{*}{$\begin{array}{c}\text { Total N } \\
(\%)\end{array}$} & \multirow{2}{*}{$\begin{array}{l}\mathrm{C} / \mathrm{N} \\
(\%)\end{array}$} & \multirow{2}{*}{$\mathrm{pH}$} & \multirow{2}{*}{$\begin{array}{c}\text { Water } \\
\text { content } \\
(\%)\end{array}$} & \multirow{2}{*}{$\begin{array}{l}\text { Particle } \\
\text { density } \\
\left(\mathrm{g} . \mathrm{cm}^{-3}\right)\end{array}$} & \multirow{2}{*}{$\begin{array}{c}\text { Bulk } \\
\text { density } \\
\left(\text { g. } \mathrm{cm}^{-3}\right)\end{array}$} \\
\hline & Soil & Air & & & & & & & & \\
\hline Paranet & 28.89 & 26.89 & 60.44 & 0.79 & 0.09 & 9.15 & 6.23 & 15.21 & 2.68 & 1.48 \\
\hline Leucaena & 34.44 & 26.11 & 44.89 & 1.34 & 0.13 & 10.1 & 6.37 & 34.08 & 2.73 & 1.36 \\
\hline Areca palm & 35.33 & 30.56 & 44.22 & 1.28 & 0.18 & 6.97 & 6.47 & 5.29 & 2.67 & 1.31 \\
\hline Coconut & 30.89 & 27.89 & 55.78 & 1.6 & 0.2 & 7.93 & 6.23 & 39.38 & 2.65 & 1.32 \\
\hline Oil palm & 27.33 & 27.11 & 52.67 & 1.12 & 0.14 & 7.95 & 6.37 & 37.18 & 2.71 & 1.54 \\
\hline
\end{tabular}

Table 2. Ant abundance, Shannon-Wiener, and Evenness Index of cocoa farms with five shade types

\begin{tabular}{|c|c|c|c|c|c|c|c|c|}
\hline \multirow{2}{*}{ Shade } & \multicolumn{6}{|c|}{ Ant abundance (unit) of each subfamily } & \multicolumn{2}{|c|}{ Shannon- Evenness } \\
\hline & M & $\mathrm{P}$ & $\mathrm{C}$ & A & $\mathrm{D}$ & $\mathrm{F}$ & Wiener Index & Index \\
\hline Paranet & 1050 & 491 & - & - & 16 & - & 0.68 & 0.09 \\
\hline Leucaena & 473 & 22 & - & 2 & 8 & - & 0.29 & 0.05 \\
\hline Areca palm & 376 & 91 & 2 & 3 & 26 & - & 0.72 & 0.12 \\
\hline Coconut & 329 & 49 & - & - & 27 & 44 & 0.83 & 0.14 \\
\hline Oil palm & 1332 & 78 & - & - & 42 & 11 & 0.38 & 0.05 \\
\hline
\end{tabular}


type that have a high foraging ability and have a character to make nests in disturbed area (Rosnadi et al., 2019).

Septriani et al. (2015) stated that an area can be said to have been invaded if Myrmicinae subfamily ant is found in that area. According to Ikbal et al. (2014) and Toana et al. (2014) the dominant macrofauna in the cocoa plantation is invasive macrofauna such as Pheidole rugosula and Monomorium sydneyense, which belongs to the Myrmicinae subfamily. The observed areas are disturbed due to human activities, such as applying insecticides and harvesting, which condition is suitable habitat for the Myrmicinae subfamily and reduce the existence of other subfamilies.

At leucaena site, there were two ants of Aenictinae subfamily trapped by Berlese funnel, and at the arecanut site was found three ants of Aenictinae subfamily and two ants of Ceraphachyinae trapped by pitfall trap (Table 2). According to Brady et al. (2014), Aenictinae and Cerapacyinae subfamilies have similar behavior and habitat. The small number of Aenictinae and Ceraphacyinae subfamilies is due to the fact that both subfamilies are nomadic (Brady et al., 2014; Willian, 1978). The native habitat of the Aenictinae and Ceraphachyinae subfamilies is leaf litter, below rocks and rotting stems and tend to be found in dry areas. Those all were mostly found in this experimental site (Brady et al., 2014;. Sharaf et al., 2012; Borowic, 2019; Borowiec, 2016).

The diversity index in all observation sites was $<1$, which indicates that the ants diversity and ecosystem stability in all observation sites was low. The highest diversity index number was 0.83 at the coconut site, although total number of individuals found was 449 ants. At the oilpalm site the total individuals reached 1477 ants, but the diversity index only 0.38 (Table 2) which means that there was a negative correlation between total abundance and diversity index. According to Haneda et al. (2013), the maximum diversity index will be obtained if the ants from each species have the same numbers. The evenness index from all observation sites is close to 0 , indicating that one subfamily is dominant in all observation sites (Table 2). During the observation, the Myrmicinae subfamily was found in all observation site and dominate with large numbers. According to Rahayu \& Wiryadiputra (2019), the evenness index close to 1 , means the distribution pattern of certain groups in the community is balanced.

Evenness index are influenced by the environmental conditions, vegetation and human activities in the plantation areas such as tillage, fertilization, irrigation weeding, burning, pruning, and application of chemical substances. Vegetation will be a food source for organisms that live in the environment, the high variation in the vegetation type will provide a higher living organism diversity. In all observation sites, the vegetation dominance (other than cocoa) was found, such as Hedyotis corymbosa, Phyllantus urinaria, Cyperus rotundus, Rivina humullis, and Urtica dioica; it makes each observation site has a different composition and structure of living organisms.

The role of each ant subfamily group affects the presence of other ants subfamily in an observation site. Ants have an important role in maintaining the stability of ecosystem composition, like the Aenictinae subfamily which is classified as a predator belong to the Formicinae subfamily; and the Dolichoderinae subfamily which is classified as a scavenger and often found in association with other organism. According to Appiah et al. (2014), every organism that lives in the ecosystem has its role, such as herbivorous insects acting as controllers of parasitic plants and weeds, while carnivorous insects can be a 
biocontrol for pests. Fabian \& Flatt (2012) wrote that every species has a specific characteristic such as prefer to the food, prefer to the habitat, and prefer to the condition that suitable to make nest.

\section{Correlation of the Ant Abundance and Pest Attack Intensity}

The highest attack intensity of $H$. antonii and $C$. cramerella was at areca palm, which reached 20.76 and $5.77 \%$ respectivly (Figure 2). High intensity of pest attack in all observation site caused by microclimate and vegetation condition that suitable for the development of C. cramerella and H. antonii (Amanda et al., 2020). All microclimate paramater in all observation site is the suitable condition for $H$. antonii and $C$. cramerella to grow (Table 1). Based on research conducted by Syarief et al. (2017) and Niogret et al. (2019) an area with high humidity and low intensity of light could stimulate the reproduction of $H$. antonii dan C. cramerella. The vegetation condition like a broad leaves from the shade plant and the variety of vegetation provide shelter for $H$. antonii and C. cramerella from sunlight, especially at coconut and leucaena. Coconut is the vegetation that become a shade plant for coconut site, the coverage of this vegetation reached $77.41 \%$ while at leucaena site has a coverage canopy reached $73.47 \%$. According to Pravita et al. (2020), H. antonii and C. cramerella will stick to the branches, twigs, and leaves of existing vegetation as a shelter and a place to rest from the sun and unsuitable environ mental conditions.

The existence of food sources like cocoa pods was a main factor for $H$. antonii and C. cramerella to live in this location (Niogret et al., 2019). Babin (2018) said that H. antonii and $C$. cramerella were more interested in attacking cocoa pod at night and rainy season because the temperature will decrease. This research was conducted during the rainy season so that cocoa pods will be more potentially attacked by pests.

In general, pest attach intensity in all treatment was low, because pest control application was carried routinely every 1-2 weeks. Oil palm site had the lowest pest attack intensity of $H$. antonii $(7.3 \%)$ and C. cramerella (2.26\%) compared to other observation sites (Figure 3). Oil palm site

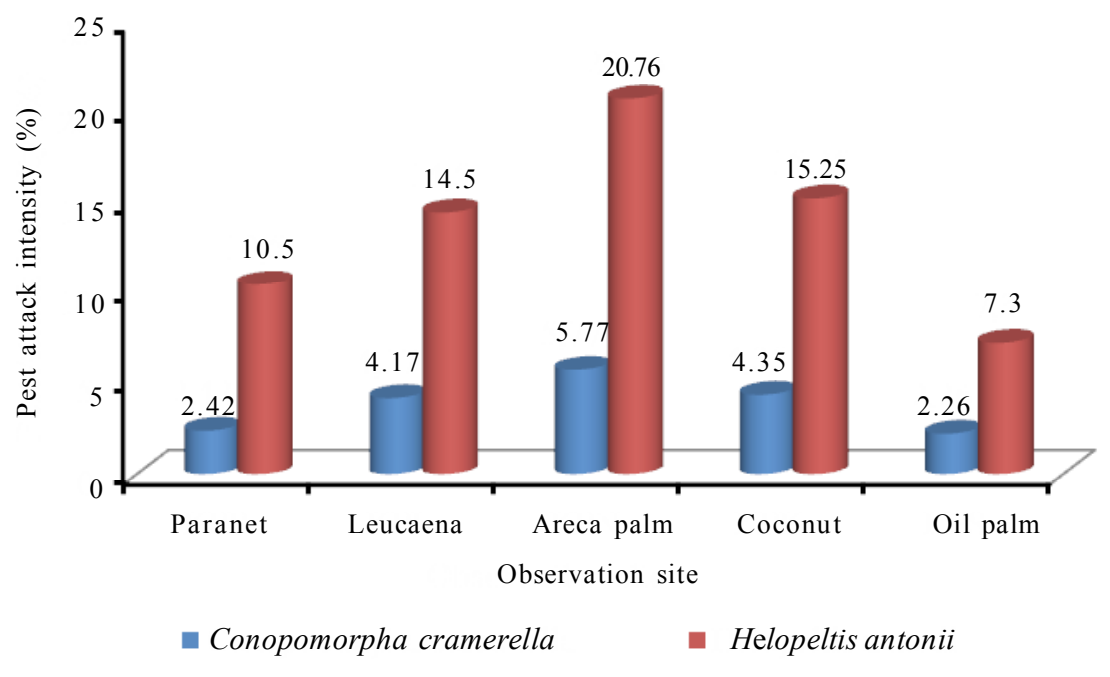

Figure 2. Pest attack intensity of $H$. antonii and C. cramerella in all observation sites 
has a moist condition with broad and wide oil palm leaves (Elaeis sp.). The variety of vegetation and abundant litter make $H$. antonii and $C$. cramerella have a comfortable life. The low pest attack intensity at the oil palm because the cocoa pod was covered by mealybug (Planococcus sp.). The coverage mealybug at cocoa pod reaching $30 \%$. The mealybugs (Planococcus sp.) attach to the surface of the cocoa pod, and excrete sugar that attract ant, so the movement of ant protect cocoa pod from $H$. antonii dan C. cramerella attack (Koch et al., 2020).

There was a negative correlation between ant abundance and intensity of attack by $H$. antonii dan C. cramerella (Figure 3). Based on Pearson correlation analysis, the correlation coefficient between ant abundance and intensity of attack by $H$. antonii was -0.632 (P-value $<0.05$ ) and ant abundance and intensity of attack by $C$. cramerella was 0.403 (P-value $<0.05$ ). According to Ridwan et al. (2020), ants can be used as a biocontrol for cocoa pods to prevent $H$. antonii and C. cramerella attacks. This correlation can be seen at oil palm, where ant abundance was 1463 unit (Table 2) and had a microclimate that can support $H$. antonii dan C. cramerella (Table 1), but the intensity of pest attack by $H$. antonii dan C. cramerella, which was classified as the lowest compared to other observation sites. Similarly, at leucaena, coconut and areca palm have a suitable condition for the development of H. antonii and C. cramerella (Figure 2). Therefore, the intensity of pest attack was still relatively high and the ant abundance was less than at Elaeis observation site.

However, it was different from the paranet site, which has ant abundance of 1557 unit (Table 2) with conditions that can support the existence of $H$. antonii and C. cramerella but the intensity of pest attack was still relatively high (Figure 2). At the paranet location there was no decrease in the intensity of $H$. antonii and C. cramerella, although there was a large abundance of ants. This happened because at the paranet location there were no ant subfamilies that acted as biocontrols, namely Formicinae and Dolichoderinae.

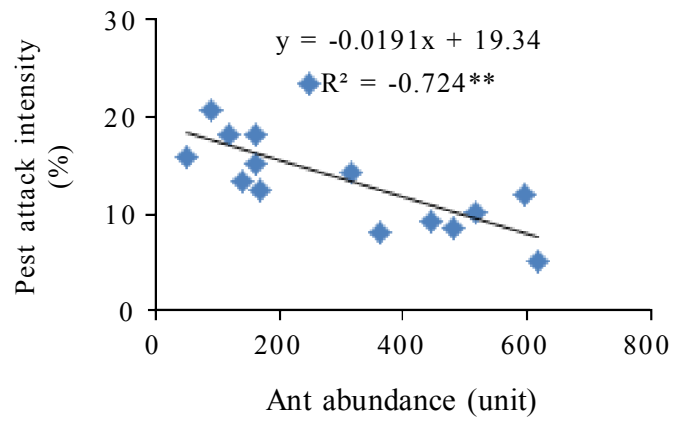

(a)

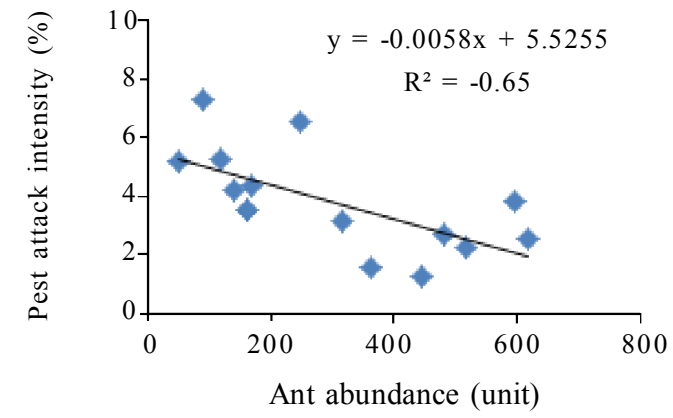

(b)

Figure 3. Correlation between ant abundance and intensity of pest attack (a) Helopeltis antonii; and (b) Conopomorpha cramerella (CPB) 
At oil palm site, Formicinae and Dolichoderinae subfamilies were found, where these two subfamilies have a role as natural enemies for $H$. antonii and C. cramerella. This is following research conducted by Forbes \& Northfield (2017) using ant from Formicinae subfamily that is Oecophylla smaragdina which can reduce the attack from $H$. antonii and $C$. cramerella by spreading pheromones around cocoa pod so that $H$. antonii and C. cramerella will avoid the pod. According to Wielgloss et al. (2014), ants from the genus Dolichoderus have the ability to control H. antonii and C. cramerella attack on cocoa plants.

\section{CONCLUSIONS}

The ants identified in this study grouped in six subfamilies with subfamily Myrmicinae are dominant at all shaded cocoa farms. The composition of ant abundance and diversity from all sites with different shades have an unique characteristic such as in coconut and oil palm that only found Formicinae subfamily. The abundance of ants has a negative correlation with intensity of $H$. antonii and C. cramerella attacks, where the more abundant ants in the observation site can reduce intensity of pest attack.

\section{ACKNOWLEDGEMENT}

The authors sincerely thank the Indonesian Coffee and Cocoa Research Institute for permission where this research was conducted.

\section{REFERENCES}

Amanda, V.F.; Yaherwandi \& S. Efendi (2020). Kelimpahan populasi Helopeltis sp. dan tingkat kerusakan buah kakao di Kecamatan Sitiung Kabupaten Dharmasraya. Agrika, 14, 33-46.
Appiah, E.F.; S. Ekesia.; K. Afreh-Nuamah; D. Obeng-Ofori \& S.A. Mohamed (2014). African weaver ant-produced semichemicals impact on foraging behavior and parasitism by the Opiine parasitoid, Fopiusa risanus on Bactrocera invadens (Diptera: Tephritidae). Biological Control, 79, 49-57.

Armaniar \& A. Saleh (2018). The use of bokashi fertilizers and biological control of cocoa pod borer (Conopomorpha cramerella) on cocoa farmers in Langkat District, North Sumatera. p. 31-35. In: Proceeding of International Conference on Sustainable Agriculture and Natural Resources Management. Medan, Indonesia.

Babin, R. (2018). Pest Management in Organic Cacao. In: Handbook of Pest Management in Organic Farming. CABI. Wallingford, United Kingdom.

Bolton, B. (1994). Identification Guide to the Ant Genera of the World. Harvard University Press. London, United Kingdom.

Borowiec, M.L. (2016). Convergent evolution of the army ant syndrome and congruence in big-data Phylogenetics. Systematic Biology, 68, 642-656.

Borowiec, M.L. (2019). Generic revision of the ant subfamily Dorylinae (Hymenoptera, Formicidae). ZooKeys, 608, 1-280.

Brady, S.G.; B. Fisher; T.R. Schultz \& P.S. Ward (2014). The rise of army ants and their relatives: divesification of specialized predatory Doryline ants. BMC Evolutionary Biology, 14, 93.

Dinesh, G.K.; P.T. Ramesh; N. Chitra \& M.P. Sugumaran (2018). Ecology of birds and insects in organic and conventional (in-organic) rice ecosystem. International Journal of Current Microbiology and Applied Sciences, 7, 1769-1779.

Ditjenbun (2021). Kakao: Statistik Perkebunan Unggulan Nasional 2019-2021. Direktorat Jenderal Perkebunan. Kemeterian Pertanian. Jakarta, Indonesia. 
Evangelista, H.B.A.; S.M. Thomaz \& L.R. Evangelista (2012). Comparison of diversity indices applied to macrophyte incidence-based data. Brazilian Archives of Biology and Technology, 55, 277-282.

Fabian, D. \& T. Flatt (2012). Life history evolution. Nature Education Knowledge, 3, 24.

Forbes, S.J. \& T.D. Northfield (2017). Oecophylla smaragdina ants provide pest control in Australian cacao. BIOTROPICA 0, 1-9.

Frouz, J. \& V. Jilková (2008). The effect of ants on soil properties and processes (Hymenoptera: Formicidae). Myrmecological News, 11, 191-199.

Haneda, N.F.; C. Kusmana \& D. Kusuma (2013). Keanekaragaman serangga di ekosistem mangrove. Jurnal Silvikultur Tropika, 4, 42-46.

ICCO (2020). Quarterly Bulletin of Cocoa Statistics: Cocoa year 2019/2020. Vol. XLVI(1). International Cocoa Organization.

Ikbal, M; N.S. Putra \& E. Martono (2014). Ant diversity in cocoa plantation ecosystems in Banjaroya Village, District of Kalibawang, Yogyakarta. Jurnal Pelindungan Tanaman Indonesia, 18, 79-88.

Kadochová, Š. \& J. Frouz (2014). Thermoregulation strategies in ants comparison to other social insects, with a focus on red wood ants (Formica rufa group). F1000Research, 2, 280.

Koch, E.B.A; T.E.D. Marques; C.S.F. Mariano; E.A.S. Neto; A. Arnhold; A.L.B.G. Peronti \& J.H.C. Delabie (2020). Diversity and structure preferences for ant-hemipteran mutualisms in cocoa trees (Theobroma cacao L., Sterculiaceae). Boletim do Museu Paraense Emílio Goeldi. Ciências Naturais, 15, 65-81.

Melo, A.S. (2008). What do we win "confounding" species richness and evenness in a diversity index?. Biota Neotropica, 8, 21-27.

Nenotek, P.S. (2018). Intensitas kerusakan oleh pengisap buah kakao (Helopeltis spp.) pada tanaman kakao di Kecamatan Hewokloang Kabupaten Sikka Nusa Tenggara Timur. p. 236-246. In: Prosiding Seminar Nasional Pertanian ke-5, Kupang, Indonesia.

Niether, W.; L. Armengot; C. Andres; M. Schneider $\&$ G. Gerold (2015). Shade trees and tree pruning alter throughfall and microclimate in cocoa (Theobroma cacao L.) production system. Annals of Forest Science, 75, 1-16.

Niogret, J.; A. Ekayanti; K. Ingram; S. Lambert; P.E. Kendra; H. Alborn \& N.D. Epsky (2020). Development and behavioral ecology of Conopomorpha cramerella (Lepidoptera: Gracillaridae). Florida Entomologist, 102, 382-387.

Olawusi-Peters, O.O. \& A.O. Ajibare (2014). Species richness, diversity and abundance of some Decapod Crustaceans in coastal waters of Ondo State, South West, Nigeria. International Journal of Fauna and Biological Studies, 5, 44-51.

Paris, C. \& X. Espadaler (2012). Foraging activity of native ants on forest fragments colonized by the invasive ant Lasius neglectus. Psyche, 2012, 261316.

Pravita, A.M.; L. Wibowo; A.M. Hariri \& Purnomo (2020). The survey of population density and attack intensity of cocoa pods sucker (Helopeltis spp.) in the cocoa (Theobroma cacao L.) plant in the District East Lampung. Jurnal Agroteknologi Tropika, $8,555-582$.

Rahayu, D.S. \& S. Wiryadiputra (2019). Diversity of arthropods and parasitic nematodes population in intercropping patterns of Robusta coffee. Pelita Perkebunan, $35,33-41$.

Rahim, A. \& K. Ohkawara (2019). Invasive ants affect spatial distribution pattern and diversity of arboreal ant communities in fruit plantations, in Tarakan Island, Borneo. Sociobiology, 66, 527-535.

Ridwan, A.; A. Gassa \& T. Abdullah (2020). Aplikasi Dolichoderus sp. untuk pengendalian Helopeltis spp. pada 
tanaman kakao. Journal of Agroplantae, 9, 14-21.

Rocha-Ortega, M. \& M.Á. Garcia-Martinez (2018). Importance of nesting resources and soil conditions for the recovery of ant diversity during secondary succession in tropical rainforest. Tropical Conservation Science, 11, 1-14.

Rosa, N.; I. Dewantara \& H. Prayogo (2019). Diversity of ant (Formicidae family) on peatland at the new building of The Forestry Faculty of Tanjungpura University in Pontianak. Jurnal Hutan Lestari, 7, 723-732.

Rosnadi, A.F.; D.A. Saputri \& M. Kamelia (2019). Ant diversity (Hymenoptera: Formicidae: Myrmicinae) in three housing types in Bandar Lampung. Jurnal Ilmiah Biologi Eksperimen dan Keanekaragaman Hayati, 6, 70-77.

Rubiyo \& Siswanto (2012). Peningkatan produksi dan pengembangan kakao (Theobroma cacao L.) di Indonesia. Buletin RISTRI, 3(1), 33-48.

Septriani, S.; H. Herwina \& Mairawita (2015). Semut subfamili Myrmicinae di Suaka Alam Maninjau Utara Selatan, Kabupaten Agam, Sumatra Barat. Jurnal Biologi Universitas Andalas, 4, 248-257.

Sharaf, M.R.; A.S. Aldawood \& M.S. El-Hawagry (2012). First record of the ant subfamily Aenictinae (Hymenoptera, Formicidae) from Saudi Arabia, with the description of a new species. ZooKeys, 228, 39-49.

Shattuck, S.S. (2001). Australian Ants Key: Their Biology and Identification. CSIRO Publishing. Canberra, Australia.
Suherlina, Y.; Yaherwendi \& S. Efendi (2020). The distribution and level of cocoa pod borer (Conopomorpha cramerella Snellen) attack in the new opening land in Dharmasraya Regency. Jurnal Agronida, 6, 46-57.

Sulistyowati, E.; Y.D. Junianto; S. Sukamto; S. Wiryadiputra; L. Winarto \& N. Primawati (2003). Analisis status penelitian dan pengembangan PHT pada pertanaman kakao. p. 161-176 In: Simposium Nasional Penelitian PHT Perkebunan Rakyat, Bogor, Indonesia.

Syarief, M.; A.W. Susilo; T. Himawan \& L. Abadi (2017). Diversity and abundance of natural enemies of Helopeltis antonii in cocoa plantation related with plant pattern and insecticide application. Pelita Perkebunan, 33, 128-136.

Toana, M.H.; G. Mudjiono; S. Karindah \& A.L. Abadi (2014). Diversity of arthropods on cocoa plantation in three strata shade tree. Agrivita, 36, 120-127.

Wielgoss, A.; T. Tscharntke; A. Rumeda; B. Fiala; H. Seidel; S. Shahabuddin \& Y. Clough (2014). Interaction complexity matters: Disentangling services and disservices of ant communities driving yield in tropical agroecosystems. p. 2013-2144 In: Proceeding of The Royal Society B: Biological Sciences, London, United Kingdom.

Zina, V.; M. Ordeix; J.C. Franco; M.T. Ferreira \& M.R. Fernandes (2021). Ants as bioindicators of riparian ecological health in Catalonian Rivers. Forests, 12, 625.

$* * 0 * *$ 